\title{
Captives of Narrative: Scandinavian Museum Exhibits and Polar Ambitions
}

\author{
By Anders Houltz
}

\begin{abstract}
This article compares the histories of two museums of polar exploration, both founded in the 1930s but based on well-known expeditions dating back to the decades around 1900. The first is the Fram Museum in Oslo, centered around the famous Norwegian polar ship, the second is the Andrée Museum in Gränna, combining accounts of the ill-fated balloon expedition with a polar centre reflecting more recent polar research activities.

The aim of the article is to analyze the relationship between museum and narrative. Museums are shapers of narrative but at the same time shaped by the narratives they relate. The article explores the symbolic and medialized dimensions of polar research, expressed in museums, as well as the way in which museums interrelate with national identities and self-images.

What does it mean to be a modern polar nation? And how is such an identity expressed in cultural terms? In which ways can museum institutions and exhibitions be used as means for such expressions? And how do "the grand narratives" of Sweden and Norway relate to the epic representations of polar activities, presented by the museums?
\end{abstract}

Keywords: Polar museums, polar history, narrative, nationalism, The Andrée Expedition 1897, The Fram Expedition 1893-96, Oslo, Gränna 


\section{Introduction}

In March 2009, the search for a pyromaniac was headline news in Norwegian media. A series of fire incidents had occurred on the museum-dense peninsula of Bygdøy, close to central Oslo. The main target appeared to be the Fram Museum, one of Norway's foremost tourist attractions. Four times in five weeks, night-time attempts were made to set fire to the conspicuous building, containing the world famous polar ship, commissioned by Fridtjof Nansen and used on three legendary Norwegian polar expeditions in the late $19^{\text {th }}$ and early $20^{\text {th }}$ centuries (Aftenposten 2009-03-11).

While the police investigation proceeded, an animated debate stirred over the national cultural values at stake, had the fire not been put out in time. Papers described the Fram Museum as a "National treasure" and the director-general of the National heritage board, Nils Marstein, stated in a press-communiqué that "The Fram Museum contains national gems representing Norway as a coastal nation. The Fram is a national icon connected to the Norwegian discoveries and scientific expeditions in the polar areas."(http://www.riksantikvaren.no, 2009-03-11).

The affair reached its outcome some weeks later, when a remorseful teenager admitted the deeds. As it turned out, the attempt to set fire to the Fram had not primarily been politically or ideologically motivated. Considering the choice of target, however, it was nevertheless a highly symbolic action. The deed, in combination with the various heated sentiments it triggered, can be understood as a confirmation of the strong symbolic position that this museum item retains in modern Norwegian culture. Other examples point in the same direction. When the daily newspaper Aftenposten organized a major public vote among its readers about "The Norwegian of the $20^{\text {th }}$ century", Fridtjof Nansen ended up in the first place, regardless that his greatest feats as an explorer were all achieved during the previous century (Aftenposten 1999-11-13). ${ }^{1}$ The narratives conveyed by Nansen and the ship Fram remain forceful and seem to stay in remarkable harmony with the modern Norwegian self-image. In other words, the Fram Museum is a Norwegian national monument.

The closest Swedish equivalent to the Fram Museum is not located in the capital, but in the provincial town of Gränna, on the eastern shores of Lake Vättern, in the county of Jönköping. Around the findings from the Gränna-born engineer Salomon August Andrée's ill-fated balloon expedition to the North Pole in 1897, a museum and polar research centre has been created, which constitutes the most prominent public manifestation to be found anywhere over Swedish research activities in the Arctic and Antarctic. If the Fram Museum enjoys a more or less unchallenged position in Norway, the Andrée Museum (officially the Gränna Museums with Polar Centre and the Andrée Expedition) is contested both in terms 
of its purpose, its content and even its existence. What is the reason for this difference?

The international literature on polar research history is extensive; early heroic portraits have gradually been complemented by critical reevaluation and studies aiming at broader socio-cultural contextualization (for instance Wråkberg 1999; Bravo \& Sörlin 2002; Avango 2005; Drivenes, Jølle et al. 2005; Friedman 2010). Public museums displaying and commenting polar research and exploration have not, however, to any significant extent been subjected to scholarly analysis (Wheeler \& Young 2000, compare Aronsson 2008). Such museums, and the way they materialize and express the narratives generated by polar travel, rather than polar journeys and exploration as such, is the issue at hand in this article.

To be able to present a strong narrative is often described as the foundation for a successful museum display. Both the Fram Museum and the Andrée Museum are indeed each moulded around such strong - and in fact interrelated - narratives. Why, then, are their positions and status so different in a national context? The aim of this article is to analyze the relationship between museum and narrative, based on a comparison between these two museums. It explores the symbolic dimensions of polar research and its museums, as well as the way in which museums interrelate with national identities and self-images. How do museum institutions and exhibitions express what it means to be a modern polar nation?

Polar exploration and explorers must largely be understood as cultural phenomena. As shown by polar historian Michael F Robinson, the most important aid of polar travelers was neither dog sledges, nor sea vessels or other kinds of equipment, but the domestic audience which followed, admired and ultimately financed the adventures of their heroes (Robinson 2006). Robinson stresses that the exploration of the polar areas depended on cultural and political preconditions on a domestic arena. The "Arctic fever" of the late $19^{\text {th }}$ and early $20^{\text {th }}$ centuries was fuelled by home audiences and venture capitalists of the industrialized countries. The Arctic was a distant stage, but its dramas both mirrored and interfered with issues more closely at hand. The "discovered" Arctic was created in the interplay between explorers and their audiences - both before the departure and after the return. In this process, I suggest, museums and their exhibitions were soon included beside other media as active creators of meaning. When the polar expeditions had long-since ceased to be headline news, museums continued to formulate, give shape to and communicate the narratives of the exploration of the world's most inaccessible places. This process went on, and still does, through the assembling, classification and presentation of collections, through the publication of catalogues and texts, and through exhibitions.

On a general level, museums serve an important role as national showcases, where more or less common identities based on selected knowledge are being negotiated and presented. In Peter Aronsson's words, "national museums do present an institution where knowledge is transformed, negotiated, materialized, 
visualized and communicated with national identity politics, hence producing a legitimate synthesis answering the question of what the nation was, is and ought to be." (Aronsson 2010: 48) To understand the similarities and differences of museums in the construction of nationalisms, Aronsson proposes an international comparative approach. This article can be described as an attempt in that direction.

In their role as creators of meaning and coherence, museums of polar exploration have actively participated in the shaping of the narratives of polar discovery and their incorporation in the grand narratives of different nations. The discursive character of museum displays has been described by the narratologist Mieke Bal in the following manner:

\begin{abstract}
Exposing an agent, or subject, puts "things" on display, which creates a subject/object dichotomy. This dichotomy enables the subject to make a statement about the object. The object is there to substantiate the statement. It is put there within a frame that enables the statement to come across. There is an addressee for the statement: the visitor, viewer, or reader. The discourse surrounding the exposition, or, more precisely, the discourse that is the exposition, is "constative": informative and affirmative. (Bal 1996: 3)
\end{abstract}

In other words, the institutionalized setting of the museum implies strong truth claims. While the object supporting the statement is visible, sometimes even tangible, the subject making the statement is usually not, and the same goes for the underlying motives or agenda behind the statement. To this I would like to add another intriguing relationship to consider in order to fully understand an exhibition. Museums are not only shapers of narrative - as this article will show, they are themselves simultaneously shaped, at times even captivated, by the narratives they display.

\title{
Two Strong Narratives
}

The two museums at issue here each have a basic storyline, to which more or less everything that the visitors experience relates. These storylines are founded in the popular interest in polar exploration of the late $19^{\text {th }}$ century and the hero worship of the explorers as individuals that went along with it (Wråkberg 1999). They are also parts of the larger stories about the international race towards the North Pole and about the formation of the modern nations of Sweden and Norway before and after their 1905 secession (Aronsson 2005; Sejersted 2005).

The defining narrative of the Fram Museum is that of the ship's first voyage. The Fram was used in another two important expeditions in the history of polar exploration - Otto Sverdrup's extensive mapping of the areas north-west of Greenland 1898-1902, and Roald Amundsen's successful race against Robert Falcon Scott towards the South Pole in 1910-12 - but more than anything else it is the story of Fridtjof Nansen's North-Pole expedition 1893-96, that sets its mark on the museum. It was for this purpose, and in accordance with Nansen's speci- 
fied requirements, that the ship was constructed by the shipbuilder Colin Archer in 1892. It is an adventurous success story which connects polar exploration with Norwegian self-esteem (Nansen 1897; Christensen 1996; Huntford \& Christensen 1996; Huntford 1997).

Nansen's plan was based on at the time unproved theories about Arctic seacurrents. The idea was to travel as far east as possible through the North-East Passage along the northern coast of Siberia, and then, deliberately, let the ship get caught by the pack ice, in order to slowly drift towards the North Pole by means of the motions of the icecap. If necessary, the last stretch would be covered on skis and dog sledge.

With a crew of eleven, the Fram sailed out from Tromsø in northern Norway in August 1893. In September the ship was fixed by the ice, as planned, in the East Siberian Sea. However, after eighteen months of ice drift, it stood clear that the ship was passing too far to the south to reach the Pole. Together with one of the crew members, Hjalmar Johansen, Nansen decided to leave the Fram in order to reach the goal on their own. After a few weeks they had reached a recordbreaking north latitude $86^{\circ} 14^{\prime}$, but were forced to give up the try and return south. Meanwhile, the rest of the crew had drifted ahead onboard the Fram, and were finally, after nearly three years, relieved from the grip of the ice north of Svalbard. For Nansen and Johansen, the return was extremely difficult. They spent the winter of 1895-1896 on an island of Franz Josef Land, before being miraculously saved by a British expedition.

The Fram Expedition was reunited in Tromsø, and started a triumphant return tour from harbor to harbor along the Norwegian coast, with a splendid public reception in Oslo (then Kristiania) as grande finale. Even though the goals of the expedition had not actually been reached, it was the return of a victor, and Nansen's position as a national hero was established. Fram, the strongest wooden sea vessel ever built, had proved its ability to withstand the forces of the ice, and was portrayed as a modern equivalent to "Ormen Lange", the legendary ship of the Viking king Olav Tryggvason. Nansen himself was not entirely alien to such associations. In a speech at the festivities in Oslo on September 1896, he described Fram as the embodiment of Norwegian national character: "The ship that carried us was sent by Norway - and it was an image of Norway". Just like Fram, he maintained, the Norwegian national character was "timbered out of faithfulness" (Arnesen 1942: 164). 


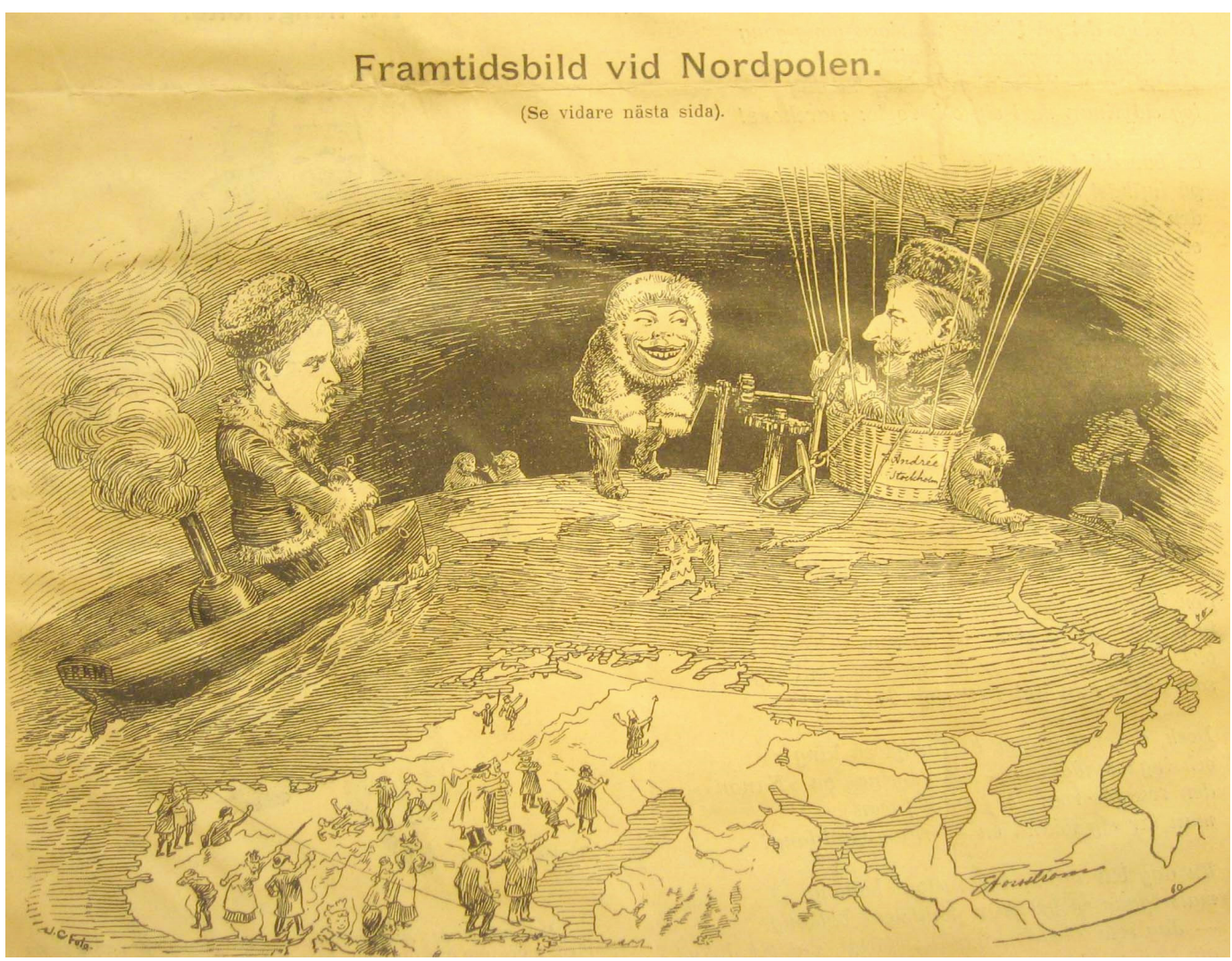

The North Pole-race between Fridtjof Nansen and S.A. Andrée was frequently commented by Swedish and Norwegian press. Here in the version of the Swedish comic magazine Söndags-Nisse (1895-02-24).

The basic narrative of the Andrée Museum is that of the engineer S. A. Andrée's fatal balloon expedition, which, just like the Fram Expedition, aspired to be the first human beings to reach the North Pole. Not unlike the Fram narrative, this drama was largely played out in front of a public audience, commencing long before the actual departure. Still, the differences are striking - in this case the story evolves around a failure, be it a grand one, and the outcome of the affair reaches the public long after the actual events took place (Andrée, Frænkel et al. 1930; Wråkberg 1998).

Late in the summer of 1896, Andrée and his collaborators were stranded on Danes Island, Svalbard, waiting in vain for favorable winds (Andrée 1896). Here they encountered the happily returning crew of the Fram, and were forced to congratulate the Norwegians to their feat. While the Fram came home in triumph, the Swedes had to return in early autumn with their tail between their legs. Still, Andrée was determined to try again - no doubt further provoked by Nansen's success, and the fact that the final goal still remained to be reached. The next summer Andrée was back at Danes Island, this time more fortunate with the winds. The expedition, consisting of three men, took off to the north. Signs of life 
in the shape of a few buoys and letter pigeons from the balloon were followed by prolonged silence and numerous speculations.

Finally, thirty-three years later, on the 6 of August 1930, the crew of a Norwegian whaler incidentally came across the remains of the Andrée Expedition, on White Island, northeast of Svalbard. The discovery included considerable amounts of equipment, but also exposed rolls of photographic film, and diaries. "The White Island Findings", as they were named, became an immediate world-wide sensation, and the long-hidden course of events became public knowledge. The diaries revealed that the balloon trip had lasted only three days, at first above open water but rapidly losing height over the ice. The expedition members finally decided to leave the balloon and start out on foot, dragging heavy loads on sledges, trying to reach solid ground, first on Franz Josef Land to the south-east, then on Svalbard to the south-west. After three months of walking they had reached White Island, where they set camp. Shortly after arrival, the three men died due to exhaustion and disease. The exact death-cause has never been fully proved. The three coffins were received in Stockholm in a ceremony that equaled Nansen's reception in Oslo in terms of solemnity, if not high spirits (Sörlin 1999).

The main character of this narrative is the expedition leader Andrée. His two comrades, Knut Frænkel and Nils Strindberg, play important side roles; their voices are articulated through notebooks and diary entries, not to mention the expedition photographer Strindberg's images, but they are still only visible in relation to their leader (for an alternative perspective, see Martinsson 2006). The intended main role of the expedition's vessel, the balloon Örnen (The Eagle), is complicated by the misfortune of the endeavor. Its premature miscarriage and abandonment makes it a metaphor over the futile tragedy of the whole expedition, but since it was never recovered by any of the search-parties, the balloon remains a shadow. In the Fram narrative, the main characters are two - Nansen himself and his ship. The human individual and the physical object are portrayed as carriers of complementary, sometimes overlapping qualities and traits, while crew members and even Hjalmar Johansen, the man who joined Nansen on the final attempt towards the Pole, are clearly subordinated. Both narratives are firmly tied to notions about masculine qualities and bravery, in line with the predominant explorer-ideal of the late $19^{\text {th }}$ century (Moland 1999).

The stories of Nansen and Andrée are involuntarily tied together, just like Norway and Sweden were caught in a union without affinity (Nilsson \& Sørensen 2005). Full of differences as the two stories are, they are both heavily framed by a nationalist discourse. The common goal, to be the first to reach the North Pole, was a task where many had failed before. Both chose unconventional methods to reach it. The Norwegian's plan was to willfully let his ship get stuck in the ice - a nightmare for seamen in Arctic waters - and then use skis and dog sledges for the finish. The Swede, engineer as he was, put his faith in the aeronautic hightechnology of the time - the hydrogen balloon. Both methods were met with skep- 
ticism by many if not all experts. In retrospect, the very methods have been fitted into a national pattern for each country. This is most evident in the case of Nansen, and also clearly articulated by himself in writing and speech. The Fram represented Norway as a seafaring nation with reference back to the Viking Age, and its exceptionally sturdy construction was a useful metaphor for the nation in its strife for independency (Nansen 1905). Even the name of the ship - meaning "forward" in Norwegian - added to its potential as a national symbol. Skiing was yet another mode of transport loaded with symbolic connotations, cherished by Nansen for reasons both practical and ideological. At the time, skiing was becoming the national sport of Norway, a process in which Nansen was actively engaged. It was no coincidence that his public break-through a few years earlier had been a ski tour - the successful crossing of Greenland on skies in $1888 .^{2}$

Andrée, on his side, was an ardent advocate of a rationalist standpoint in scientific, social and political matters. To him, reason and engineering could overcome all imaginable obstacles, and the balloon voyage was meant as an ultimate proof for this assumption. Trying to reach the goal by air, when many had failed to do so by crossing the icecap, was to trust the new technology with one's life at stake. If successful, the achievement would doubtless have been seen as a confirmation not only of Andrée as an engineer, but of Sweden as a modern, technological nation.

\section{Museum Plans in Sweden and Norway}

Although there had been earlier plans to make museums about both Fram and the Andrée Expedition, it took a number of publicly noticed events around 1930 to trigger their actual implementation. In June 1928, Roald Amundsen, the discoverer of the South Pole, died in a plane accident close to Bear Island, in the attempt to rescue the Italian Umberto Mobile and his wrecked airship expedition. Two years later, Fridtjof Nansen died and was honored as the national hero that he then was, with a grandiose funeral in Oslo on May 17, the National Day, in 1930. On November 26 the same year, Otto Sverdrup, commander of the second Fram Expedition and mate on the first one, also passed away. Within three years, the most prominent Norwegian explorers in history and all three of Fram's commanders had died. In August, 1930, finally, the sensational discovery of the White Island findings was cabled to newspaper offices around the world. All of these events were covered in detail by an international press. Biographies, homages and recollections were published in several languages. Both Sweden and Norway were taken by a sudden revival of old sentiments. But how were the polar heroes' memories to be honored and preserved? What monuments would be the most fitting, and where were they to be located?

The Norwegian debate soon focused on Fram itself. The ship was owned by the Norwegian state, and ever since Amundsen's South Pole expedition, it had been 
left with a minimum of maintenance. Preservation initiatives were taken on several occasions, but meanwhile the decay was proceeding at such a rate that the demasted vessel was close to sinking. A committee had been formed already in 1925, headed by Otto Sverdrup himself, but the fund-raising went slowly. After Sverdrup's death, the chairmanship was taken over by first the whaling shipowner and shipbuilder Lars Christensen and later the brewer Knud Ringnes. Together with other influential businessmen and industrialists, they managed to give new impetus to the work. The Ringnes Brewery, once one of the sponsors of Nansen's Fram Expedition, donated considerable capital. In 1931, the state assigned the formal ownership and responsibility for Fram to the committee. A renewed campaign was started, aiming for preservation but also for creating a specific aura around the ship. Newspapers were enrolled, fundraising among the public and a "Fram-lottery" contributed to strengthen the image of the Fram as a concern for all Norwegians, a uniting symbol for the young nation and its people (Arnesen 1942).

The fact that the initiative came from private actors was significant. While the state had neglected the ship, private citizens now seized responsibility for its preservation. The leaflet Fram-Avisen urged every nation-minded Norwegian to support the Fram-lottery. The Viking rhetoric from the celebrations back in 1896 was wiped off and given a new lease of life. Fram became the symbolic link between a past Norway, in the shape of the mythical Viking ship Ormen Lange, and a modern nation, illustrated by contemporary Norwegian tank ships. "If we mention the name Fram, Norway with all its thousands of homes arises before our eyes. For it was in that ship that we rediscovered ourselves, to new deeds after our fairytale sleep." (Fram-Avisen 1935).

The Norwegian efforts to raise money for a museum and to reconstruct Fram as a national symbol, became a lengthy process. The Swedish issue of a museum over Andrée evolved more rapidly, at least to begin with. Already the day after the news about the White Island Findings reached the headlines, the newspaper Svenska Dagbladet roused the question of a museum. The retrieved artifacts were immediately labeled relics, and as such they clearly deserved a fitting repository. The question was where, and under whose responsibility (Svenska Dagbladet 1930-08-24).

Many felt summoned. Andreas Lindblom, director of the Nordic Museum (Nordiska museet), Sweden's central institution for cultural history, immediately offered the Main Hall of his museum for an exhibition. He asserted that the impressive room, dominated by a statue of the nation-building king Gustav Vasa, would be appropriate for the purpose: "With its Gustav Vasa statue, it is, after all, meant to be a national monument. An Andrée exhibition, honoring the memory of a great Swede, would be in its proper place in such a surrounding." (Svenska Dagbladet 1930-08-24) In the longer term, however, he suggested that the $\mathrm{Mu}-$ seum of Natural History would be the most logical hosting institution. There, the 
expedition's scientific material could be connected to scientific collections and in time provide the foundation for a major display over polar research.

The director of the Museum of Science and Technology, Torsten Althin, in turn, declared that his museum already possessed some eighty items related to Andrée. In its projected, permanent museum building, he hoped to include a special "Andrée Room", at once "a valuable source of study material for engineers and scientists, and a lasting memory over Andrée and his achievements." (Svenska Dagbladet 1930-08-25) Others yet proposed an entirely new Andrée Museum in the capital, to serve as a national monument commemorating both the expedition and Swedish polar science in general. Finally, voices were heard from Andrée's birth-town of Gränna, stating that no other site could be more natural than the native place of the unfortunate expedition leader himself. In such a provincial setting, the advocates declared, the museum would be more to its profit than in the museum-crammed capital. The issue was mainly pursued by the locally powerful A E Bolling, known as "the King of Gränna", among other things chairman of both the Municipal Council and the Folklore Society. He recognized the potential in underlining Andrée's double identity as a native of Gränna and polar hero. In the local newspaper Grenna Nya Tidning, he stated that a museum would bring considerable economic effects: "The placing of the Andrée Museum in our town would mean much to the whole community, due to the stream of tourists it would attract." (Grenna Nya Tidning 1930-09-02)

The location and presentation of the findings was a question ultimately related to how the "relics" and the Andrée expedition as such were to be defined and evaluated. An exhibition in the Great Hall of the Nordic Museum would be to define Andrée and his comrades as first and foremost national heroes, to move the collection to the Museum of Natural History would be to emphasize their character as scientists and polar researchers, while locating it at the Museum of Science and Technology would stress Andrée's identity as an engineer and the voyage as technological achievement. A museum in Gränna, finally, would put focus on Andrée's local roots, and thus in all probability either hazard his status as a national concern or undermine the capital as the obvious location for such concerns. The final decision was in the hands of the Swedish Society for Anthropology and Geography, SSAG, which had been appointed the official trustee of the findings.

The short-term solution finally chosen by SSAG, was to meet the acute public interest through a hastily organized exhibition on relatively neutral grounds, in the Liljevalchs Art Gallery in Stockholm, during spring 1931. Through this compromise, the heroic, scientific and technological aspects of the Andrée Expedition were all subjected to its value as a sensational news item. Furthermore, national status was prioritized at the expense of local by placing the exhibition in the capital. 


\section{A Temple on Bygdøy}

In May 1935, the Fram was towed on its last journey, from the harbor of Horten to Bygdøy in Oslo (Aftenposten 1935-05-06). There, a modern styled museum building was erected around the stranded ship. In spite of its functionalist vocabulary, the architecture showed references to both Viking houses and medieval cathedrals with pointed vaults; all constructed in concrete, glass and wood. The steep, sloping roof-sides were coated with copper from ridge to base. The building was designed by the Norwegian architect Bjarne Tøien, who had won the architectural competition with his entry, "Saga". The inauguration was planned to take place on National Day, May 17, 1936, but was delayed until three days later.

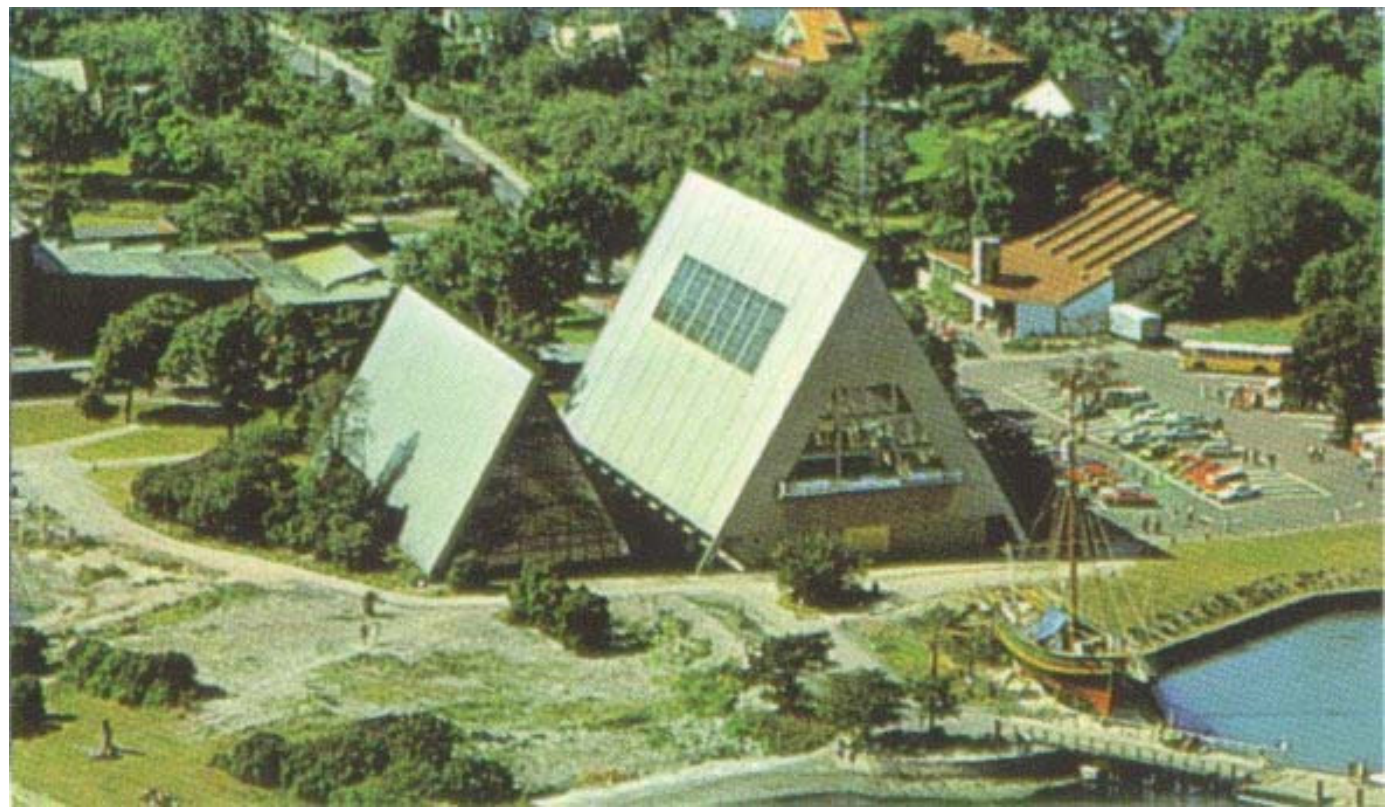

The Fram Museum stands on Bygdøy like a modern temple over Norway as a polar nation (postcard).

The conflicts had been numerous. Most parties agreed that a museum should be built, but the choice of location was a matter of controversy, as was whether the new museum should be incorporated into the existing Maritime Museum or form an individual institution, threatening to over-shadow the older museum (Dagbladet 1934-05-24). Influential property owners on Bygdøy objected to having a large modernistic building and a tourist attraction as a neighbor and managed to delay the process considerably (Tidens Tegen 1934-10-03). Some critics, however, questioned the content of the museum on a more principal level. In Dagbladet, the journalist Johan Borgen questioned the reasons for "worshiping dead symbols" when modern Norwegian research on Svalbard was in need of financial support in order not to be pushed aside by Russian initiatives (Dagbladet 193408-11). "Why is the Fram holy" asked the signature "Rasle" in a critical article: "All ice-covered sea is by now discovered, and we do not need such symbols an- 
ymore. We have no room for more of this polar manliness." (Morgonbladet 193410-20) The critical voices gradually silenced, however, and by the time of World War II, the Fram Museum was an established institution in the museum landscape of Oslo, yearly attracting some 20000 visitors.

The museum was entirely adapted to accentuating its central artifact. The entrance was centered right before the ship-stern. A bust of Fridtjof Nansen and a full-figure statue of Roald Amundsen (both later replaced by a single full-figure of Nansen) greeted visitors in front of the ship, thus establishing the main characters right from the start. The floor was lowered, so that the Fram could be observed from below, and side-galleries along the walls followed the waterline and ship deck levels. Another two galleries allowed the ship to be viewed from above. The dimensions, the massiveness and the sheer strength of the construction were clearly brought to the light. An essential factor was that visitors were allowed to actually enter the ship and move about more or less freely above and below deck. Objects and scientific equipment from the polar voyages were displayed in the saloon, but also in the corridors and cabins, along with personal belongings from the different expedition members. Small brass plates by the cabin doors named the respective inhabitants during each of the three Fram expeditions. Framed photos and paintings showed scenery and episodes from the trips. The exceptionally strong diesel engine, which had been kept at the Technical University of Norway, was renovated and returned to its proper place, where it could be observed in the machine room below. By moving about on the confined space of the ship, the visitors could form at least some notion of life on board.

Early versions of the museum plans included a small commemorative chapel, supposed among other things to house the urn containing Fridtjof Nansen's ashes (Dagbladet 1934-08-12). Although the chapel was never actually carried into effect, the very idea strongly underlines both the sacral quality of the museum and its close symbolic ties to Nansen as a person.

The exhibition mediated a condensed polar history, in which Norway, Norwegian explorers and of course the Fram were in total focus. Manly exploit and resolution, personified by the three expedition leaders, combined with the strength and endurance embodied by the Fram, implicitly depicted Norway as a nation. The rest of the world - be it other countries as polar nations or the Arctic and Antarctic as physical environments - were reduced to background roles and stage settings.

Also during the war and the German occupation, the museum was mostly kept open. In these years, a new dimension was added to the symbolic content of the Fram. As during the 1905 dissolution of the union between Norway and Sweden, the Fram was again used to personify the Norwegian will to independence and ability to endure hardships. This is evident in the journalist Odd Arnesen's book from 1942 about Fram and its history, typically titled

"Fram: A ship for the whole of Norway" (Fram: Hele Norges skute, Arnesen 1942). In the final sentences of the book, Arnesen implicitly ties the national crisis 
and independence movement around the turn of the century to the current situation in occupied Norway: "Fram and the spirit that emerged from that ship, created a greater Norway. It gave us the strength to carry on during the struggle for separation in 1905 - when the gathering call once more sounded - Fram!/.../ Therefore the Fram stands today in its house of steel and concrete and glass, urging us towards new deeds, south and north, where Norwegians have left their mark for centuries, new deeds, showing that we will never surrender in the peaceful struggle between nations." (Arnesen 1942: 290-291) The words appear to be carefully chosen; a more overt appeal for resistance would hardly have passed the censorship of Quisling's Norway.

\section{The White Island Findings on Their Way to Gränna}

The Andrée Exhibition arranged by SSAG at Liljevalchs in Stockholm the spring of 1931 was just as successful as could be expected. To meet the public response, the museum extended opening hours to include evenings throughout the week, but still the queues were long (Svenska Dagbladet 1931-01-11). Curiosity seemed insatiable about the unique images, developed after 33 years in the ice, the contents of the diaries and, not least, the many objects that had been retrieved (the commented catalogue includes 550 item numbers).

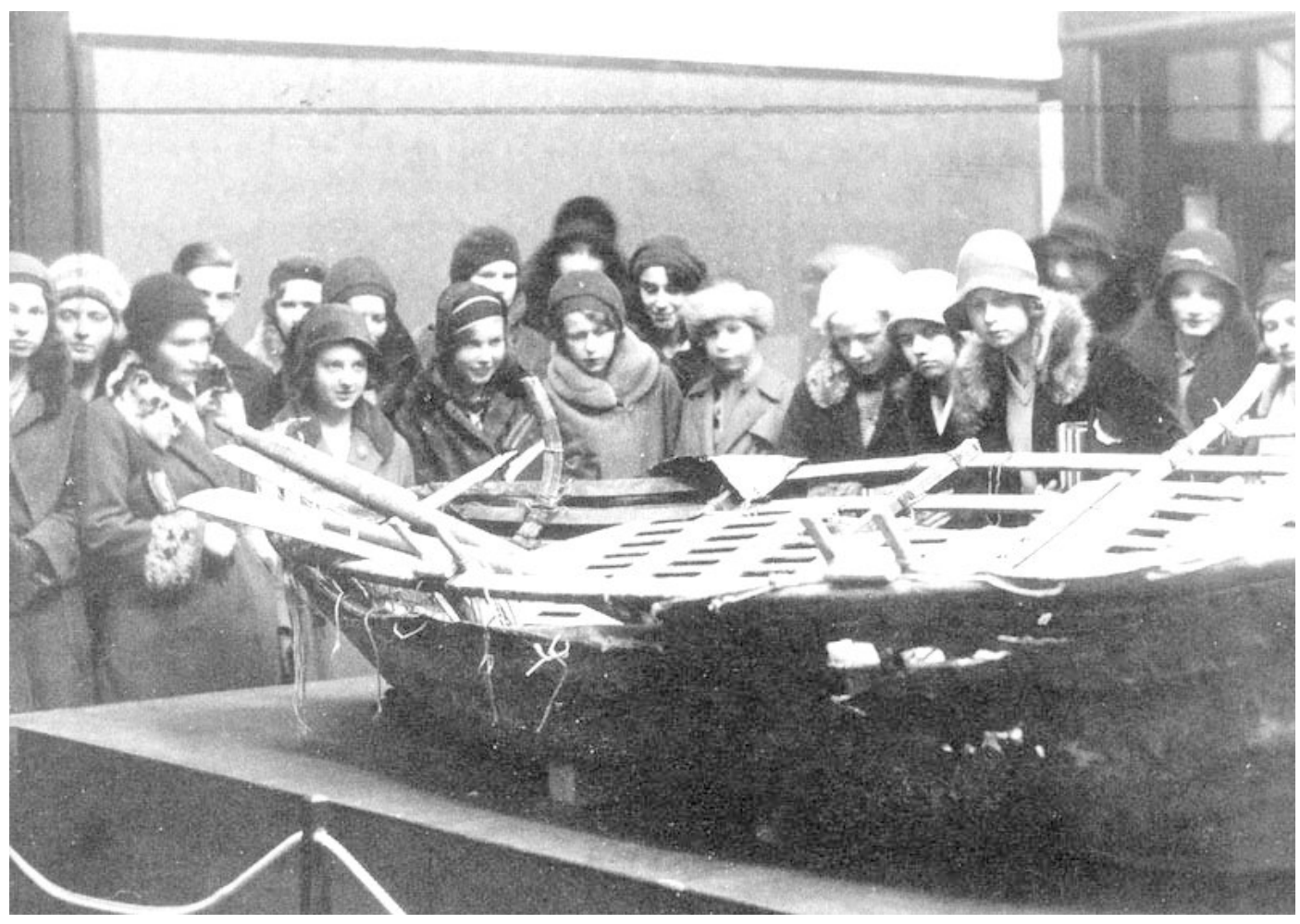

Curious visitors watch the remains of the expedition canvas boat at Liljevalchs art gallery in 1931. (Photo: Tekniska museet) 
One of the rooms was filled with maps and designs over the finding location on White Island, accompanied by a skiopticon projector showing a number of the expedition's photographs. The largest room contained the majority of the physical objects, with the expedition's canvas boat and three sledges placed at the centre. A plain-looking boathook engraved "Andrées polarexp. 1896" had been prominently placed, since it was this small object that first called attention to the ice and snow covered spot on White Island. The other rooms displayed scientific instruments, clothes, personal belongings, the remains of food supplies and travel pharmacy. The objects were presented in simple display cases, organized as far as possible in accordance with the relative positions in which they had been found. The time focus was clearly set on the moment of rediscovery in 1930, rather than the tragedy in 1897. In other words, it can reasonably be argued that the exhibition was first and foremost dealing with the current sensation, the findings, and only secondly with the Andrée Balloon Expedition (Svenska Dagbladet 1931-01-05).

The exhibition at Liljevalchs by no means made Gränna officials give up hope about an Andrée Museum in their city. Already in autumn 1930, weeks after the findings, the municipal council decided to create a small museum in the local community centre (hembygdsgård), incidentally located right across the street from Andrée's house of birth. In May 1931 the Andrée Museum in Gränna was inaugurated, receiving considerable media attention. Regardless its local setting, the ceremony was shaped as a national manifestation and was broadcasted directly on national radio and covered by the national newspapers.

The museum itself was a relatively modest arrangement, in marked contrast to the high pitch of the opening ceremonies. The hopes of accessing the White Island Findings after the termination of the exhibition at Liljevalchs had not been fulfilled. Many of the photographs were certainly reproduced in the exhibition, but in terms of physical objects, the museum had to make do with Andrée-related items from the dispersed childhood home, hastily collected by the Folklore Society. With the exception of one of the three sledges, lent out to the Gränna museum for a couple of months, the artifacts of the White Island Findings, which would have made up the obvious main attractions of the museum, were indeed conspicuous by their absence. In spite of persistent requests from Gränna, they remained stored in Stockholm localities awaiting a permanent institutional solution (Törnvall 2002).

The opening of the museum was one in a row of actions aiming to posthumously anchor Andrée and his balloon to his native town, which he had permanently left in his early teens. The first initiatives in this direction had been taken long before the destiny of the expedition was revealed. In connection to the thirty years-anniversary in 1927, for instance, a metal memorial plate was placed on the façade of Andrée's childhood home. With the White Island Findings, efforts to reconstruct Andrée as a local persona were intensified. The municipal council immediately but unsuccessfully requested that the expedition members should be buried in Gränna instead of in the capital (Grenna Nya Tidning 1930-09-16). The 
local press took all opportunities to emphasize the hometown connection, publishing detailed articles with headlines like "From the cradle in Gränna to the polar ice grave" and "Son of Gränna - National hero." (Grenna Nya Tidning 1930-0826; 1930-09-19) Even the roots of Andrée's interest in balloon-flying were sought in Gränna: "Flying and the higher regions had always appealed to him: it is said that he started his expeditions already as a child, by climbing the pipe drains of his parents house." (Grenna Nya Tidning 1930-08-26) The strings to his native town that Andrée had cut off as a schoolboy were energetically retied.

The Folklore Society, headed by the tireless A E Bolling, was the key agent in this process. A central activity was to create an Andrée collection as quickly as possible. Calls and appeals for objects connected to the balloon flyer and his family were published in the local press. Acquisitions of ever so far-fetched relevance, such as "a unique original photograph of Andrée from his school years in Jönköping" or "an old medicine cabinet belonging to the late pharmacist Andrée" were noticed and commented on in the newspaper in terms of relics (Grenna Nya Tidning 1930-11-07; 1930-10-24).

Through the years, Gränna continued to contend for the White Island Findings. When the Folklore Society in autumn of 1931 simply refused to return the borrowed sledge to SSAG in Stockholm, the controversy even became a legal case. ${ }^{3}$ In 1938, a special, purpose-built museum building was inaugurated in connection to the existing museum, but to no use. Instead the Folklore Society had to arrange a more or less provisional "Lake Vättern Museum" in the new building. During the Second World War, the White Island Findings were stored on different locations in Stockholm. Then in 1945, in the final stage of the war, Gränna made a renewed request, calling attention to the bad storage conditions. This time, the persistent endeavors were finally crowned successful. ${ }^{4}$

It is reasonable to ask why it was so important for Gränna to have its Andrée Museum. It is equally justified to ask why the resistance in Stockholm was so firm, even though the artifacts mostly were kept in store, to little use for anyone. A final question to be answered is why this resistance gave way all of a sudden, when it did.

One answer to the first question is that Gränna was and is a tourist town, where a museum with unique content could provide a valuable attraction. But other aspects are also important: in the small town community, Andrée and his achievement represented something unfamiliar, detached from everything local and familiar. The Andrée Museum was a window to the big world outside, through which Gränna, known mostly for its production of a special kind of peppermint candy "polkagris", could connect to events that had become history.

The resistance in Stockholm was officially motivated by research issues; the material and specimens collected by the expedition was valuable for Arctic scientific research, it was stated - although few scientists seem to have actually used them. ${ }^{5}$ Furthermore, the ability of the Folklore Society to take care of the collec- 
tion in a proper and professional way was questioned. Finally, plans were still entertained about creating a future Swedish museum of polar research in Stockholm. Maybe the most important thing was that the Andrée Expedition had been defined once and for all as a national concern - moving the collection from the capital would imply a reevaluation in this aspect. That the change occurred when it did may have to do with the fact that the kind of polar research that Andrée represented was becoming more and more out-of-date after half a century. Neither symbolically, nor in its content did it have very much in common with Swedish post-war research ambitions. The White Island Findings had become a matter of prestige, but they were also gradually becoming a burden, from which the SSAG was not unwilling to be relieved.

On May 3, 1946, the renamed White Island Museum (Vitömuseet) was inaugurated in Gränna. The official changing of the name from the Andrée Museum to the White Island Museum was done to mark the fact that the much longed-for collection now finally was present. A new building had been added hastily to the museum complex, in order to house the additions. A short notice in the national daily newspaper Svenska Dagbladet characterized the event as the end of a prolonged battle: "After fifteen years of stubborn fight against Stockholm over the findings made on White Island, E A Bolling, the energetic chairman of Gränna Folklore Society, has finally gained victory." (Svenska Dagbladet 1946-07-18)

Compared to the commotion caused by the much smaller museum in 1931, general interest in the White Island Museum opening 1946 was modest. None of the major papers, not to mention radio, reported from the opening ceremony. Although the local paper reported extensively, the tone was somewhat more distanced this time: "The opening of the White Island Museum last Sunday was a memorable occasion, and even if it did not turn out to be a public event of any larger proportions, many well-known and esteemed persons attended, thus adding a certain lustre to the celebration, and proving the significance attached in high places to the fact that the White Island Findings have finally received a worthy location." (Gränna Tidning 1946-07-23)

The first, 1930s version of the Andrée Museum in Gränna was a memorial room, a place for sorrow and contemplation over the town's great son. In this character it contrasted to the temporary exhibition at Liljevalchs in Stockholm, which was a tactful but still parade of the sensational findings. Including the White Island Findings in Gränna in 1946 did not essentially change the general character of the museum. It remained a mausoleum with a combined local and national discourse where the wreath-ribbons from the funeral were still displayed; the solemn mood aptly captured by the motto over the entrance: "Relics brought to the mother land, inducing reverence and devotion."6 


\section{Ageing Institutions and Modern Relevance}

The Fram Museum is located on Bygdøynes, splendidly overlooking the seaapproach and central parts of Oslo. Visitors can choose between two ways of access: by boat from the City Hall Quay on the opposite side of the Oslo Fiord, or the land-route by car or by buss. Both approaches provide a fitting framing of the visit. The short sea-trip is a reminder of the Norwegian sea-faring tradition and the natural preconditions that made for its emergence. Visitors choosing to arrive by land pass by a number of nationally charged cultural institutions along the wandering road across Bygdøy, ending with a turning space right in front of the Fram Museum. The Norsk Folkemuseum, one of the world's first open-air museums, with a medieval stave church as a highly visible centerpiece, is followed by the Viking Ship Museum, containing the uniquely well-preserved $9^{\text {th }}$ century ships from Gokstad and Oseberg. Finally, in the direct vicinity of the Fram Museum, are the Museum of Naval History and Thor Heyerdal's Kon-Tiki Museum. As the Norwegian cultural historian Anne Eriksen has pointed out, the Fram thereby becomes part of a network of significance, made up by these memorial institutions taken together. None of them is locally focused or related to Bygdøy. They all speak to, and about, Norway and the Norwegians as a nation (Eriksen 2005; see also Eriksen 2009).

The Fram Museum has remained remarkably intact along the years. To a large extent, this can be explained by the building itself; shaped as it is around its central artifact, it leaves little option for radical alterations. Exhibitions have been added, improved or updated without changing the central themes or main narratives. The most thorough transformation was carried out for the centennial of Nansen's 1893 departure towards the North Pole. That was when Per Ung's fullfigure sculpture of Nansen was added in front of the ship's stern. Faded maps and photographs were replaced by back-lighted blow-ups. While most of the older pictures had showed the welcoming festivities after the Fram's three expeditions, added images portrayed the encounter with the polar areas in different ways. Stuffed penguins on rocks and ice-flakes against painted backgrounds represented the Antarctic nature. Polar bears - the obligatory feature of every polar museum together with seabirds similarly illustrated the Arctic. Exhibition texts were translated to no less than seven languages to meet the requirements of the large numbers of foreign visitors. Sound effects like engine noise from the machine room and sledge-dogs howling from the store rooms added to a more realistic effect (Aftenposten 1993-06-21).

Still, the face-lift did not include any radical revisions of the museum's basic narratives of manly heroic exploits and Norway as a glorious polar nation. If anything, the storyline was further accentuated by the imposing statue of Nansen in front of the ship. The Fram Museum was, and remains, a national shrine, a place narrating a condensed story of Norway and Norwegianism to school classes and 
foreign visitors. In this sense, it can be categorized as what the museologist Ragnar Pedersen terms a Memorial museum (Pedersen: 41). These institutions, usually based on historically significant events, phenomena or individuals, represent and mediate a society's central values in a concrete form. The symbolic significance attached to them grant them strong powers of communication. Pedersens Norwegian examples are the Eidsvoll Museum (commemorating the constitution) and the Nidaros Cathedral in Trondhiem. Both are essential to Norwegian self-understanding, and so is the Fram Museum. In addition to its prominent position in the capital's urban landscape and on its tourist track, it holds a key place in the Norwegian national consciousness.

In comparison, today's Andrée Museum appears peripheral from several aspects. The geographical location is no less peripheral in a national perspective today than it was in the 1930s, and the polar centre is strange in its local/regional setting. Even more disturbing: the major storyline, although still retaining its potential to move and its metaphorical qualities, is hardly in tune with the grand narrative of modern Sweden, as a cultural, political or scientific project.

In contrast to the Fram Museum, the Andrée Museum has kept strong local ties though the years - strong but not unproblematic. For many years the fight for the museum remained a unifying but at times also dividing task for the Folklore Society. It was a question about priorities and allocation of resources, but also about local identity, self-image and recognition. How was the Andrée material to be fitted into the local history of Gränna; how was the "balloon-town" to be combined with the "candy-town"? As former museum director Sven Lundström pointed out, the early Andrée Museum depended largely on the personal recollections, accounts and sentiments of the visitors themselves concerning the events of 1897 and 1930 (Lundström 1991). To many, the museum was a place where personal, individual experiences could be connected to common, shared experiences. For a long time, no further justification was needed. As the part of the audience with personal memories of the events diminished over the years, however, these points of reference inevitably faded and lost their relevance. The museum needed to find new roles to play.

In the late 1960s, novelist Per Olof Sundman's acknowledged book The Flight of the Eagle (Ingenjör Andrées luftfärd, 1967, Oscar-nominee film version by Jan Troell in 1982) initiated a critical reevaluation of S A Andrée as national hero, which had hardly been possible earlier. Rather than personal courage, Sundman stressed irresponsible self-delusion, blind faith in technology and hubris as central to Andrée and his actions. In this version, the main character of the story was turned into a modern version of the mythical Icarus (Rydén 2003). Partly influenced by the revised image, some critical perspectives on Andrée's motives were included in a new exhibition at the Andrée Museum in 1979. At the same time, the wreath-ribbons from the 1930 funeral were finally removed from the exhibits (Lundström 1991; Joriksson 2002). 
The considerable attention received by Sundman's novel and Troell's motion picture did not alter the fact that the Andrée Museum was in increasing need of conceptual renewal, not to mention new facilities, to avoid being marginalized. In 1990, a seminar, aptly titled "The Andrée Museum in 1997: A future for the past", was arranged to formulate a new vision for the museum at the prospect of the coming centennial celebration of the expedition (Lundström 1991). Designs for a new building were presented, but the aim was more ambitious than that; the objective was to find new meanings for a strong but largely out-dated story. The seminar made clear that the only possible way forward was to firmly place Andrée in a historical context, but at the same time make room for other, more modern, kinds of polar research than the one represented by the Andrée expedition. This double ambition, condensed into the vision of a polar research centre of a national and even international scope, characterized much of the renewal work that was carried out under the following decade (Göteborgs-Posten 1993-03-28).

It was a matter of course to the scholars and museum curators of the seminar that Andrée and polar history was to be the main focus of the museum also in the future. That this view was not shared by all became clear in a debate in the newspaper Jönköpings-Posten some ten years later, when the projecting of the new museum was finally moving towards completion. A published letter to the editor stated that many locals felt Andrée and what he represented had been allowed to take up too much space and attention, at the expense of more regionally anchored exhibitions:

\begin{abstract}
What we want is a living, exciting museum, not a house for the dead, shaped by a foolish deed that had no relevance to anyone but the parties directly concerned and their competitors.// When we see the grand plans for a new polar centre, we ask ourselves: is this really what the people of Gränna would want? (Jönköpings-Posten 2000-07-25)
\end{abstract}

In its answer, the museum direction asserted that Andrée indeed was a relevant part of the local history, and that the Andrée material, still carrying considerable attraction, could be a means to create a modern cultural centre that would benefit also the (rest of the) local history. Nevertheless, the direction firmly stated that "We will never produce a permanent local historical exhibition." Recurrent temporary exhibitions of such content, however, could be arranged in connection to the new polar centre. (Jönköpings-Posten 2000-08-03)

When the new museum opened in 2002, in a new building on the same location as its predecessor, the ambivalence between local values and polar aspects was immediately visible. Together with tourist information, public library and auditorium, the museum comprised The Grenna Cultural Centre (Grenna kulturgård). In this new complex, the Andrée exposition and the Polar centre were placed on the basement level, while a substantial local historical display met the visitors on the main, entrance level (although somewhat confusingly preceded by a stuffed polar bear in the entrance, serving as a teaser for the basement exhibits). In a vast cen- 
tral opening between the two levels, a life-sized copy of the balloon "Örnen" (used in the motion picture from 1982) served to symbolically underscore the connection between the two parts of the museum.

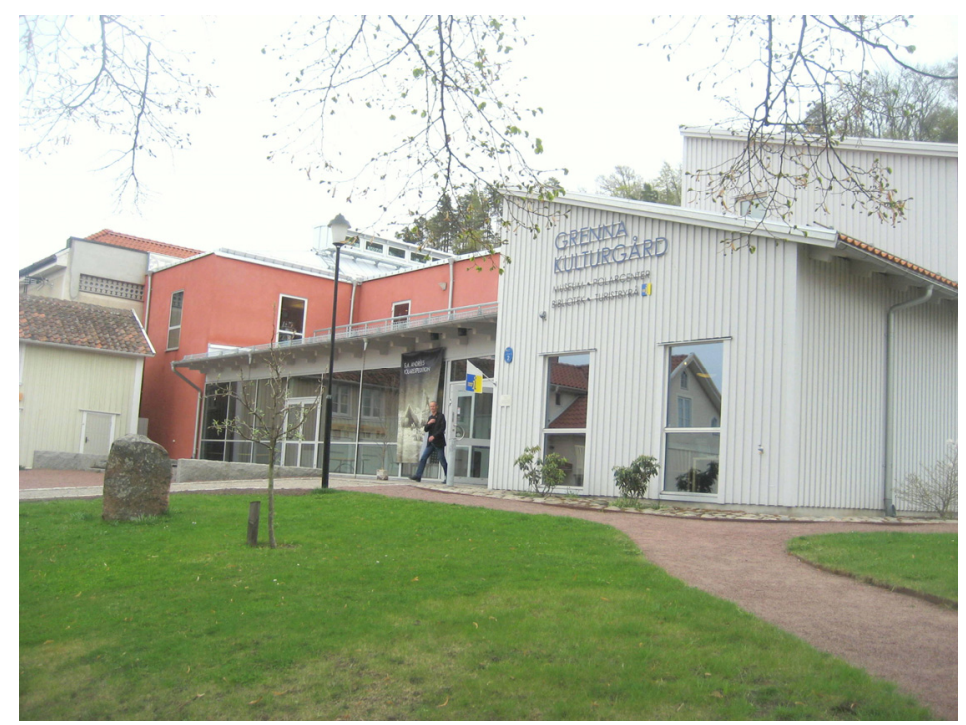

The entrance of the Grenna Cultural Centre, inaugurated in 2002 (photo: Anders Houltz).

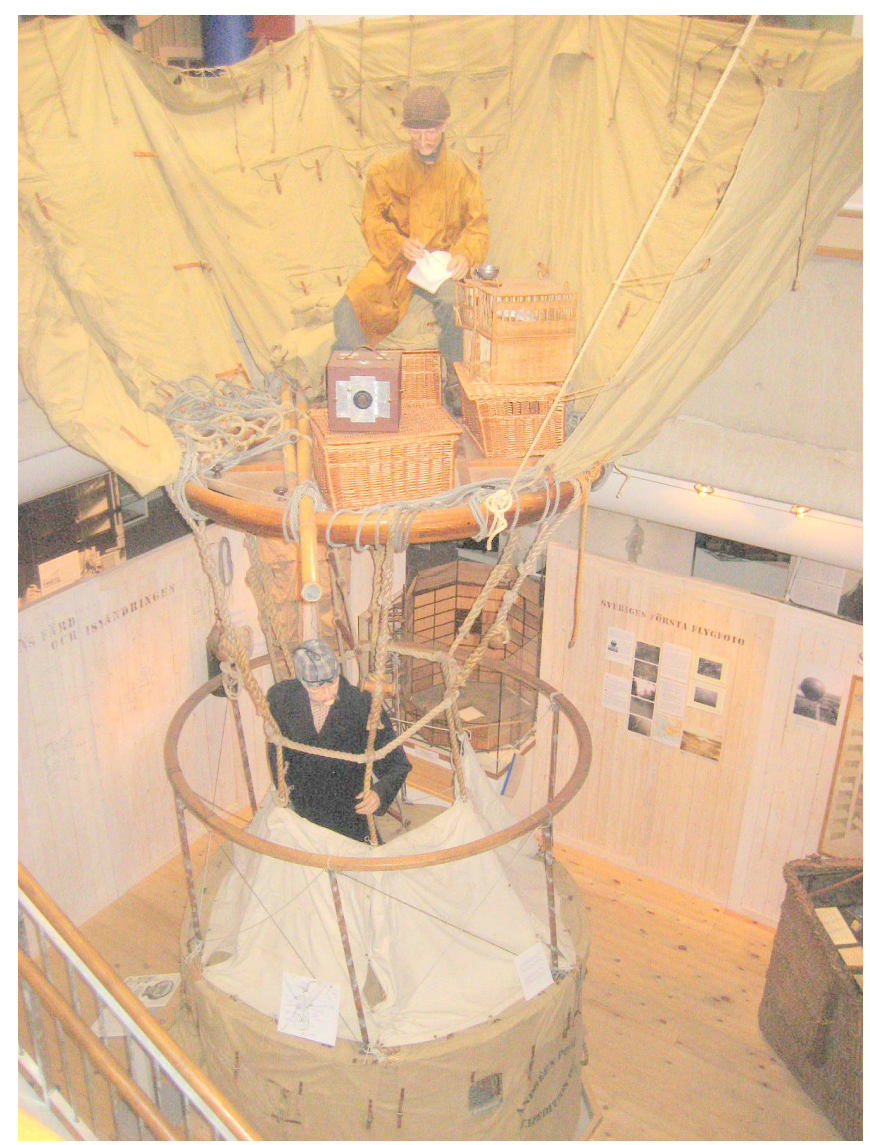

Jan Troell's film version copy of the balloon Örnen, strikingly placed in the centre of the museum exhibition space (photo: Anders Houltz). 
The museum direction's declarations two years earlier about a museum without permanent local historical exhibitions had obviously been given up. The history and heritage of the region were in fact a prominent theme of the new museum. Still, many of the ideas from the seminar in 1990 had been carried through, be it in a smaller scale than initially envisioned. The basement contained a contextualizing Andrée exhibition, aiming to make both the expedition and its failure understandable in relation to the historical situation in which it was played out. A majority of the artifacts from the White Island findings were on display and a wide-screen, $360^{\circ}$ projection of contemporary photos of the 1930 finding site related to the recovered photos from the expedition. Another section was devoted to more recent polar research in the Arctic and the Antarctic, especially but not exclusively displaying Swedish activities. Research from the recurring International Polar Years, the most recent in 2007-2008, was emphasized. Together with databases, archives and interactive workstations, this comprised the polar centre of Gränna. The museum as a whole can be viewed as a compromise. It was a local museum, but also a display over the grandest failure of Swedish polar research, and a centre for communicating modern science. At once local, national and international, at once historical and contemporary, but none of these ambitions carried out to its full potential. The unifying link between the different focuses was still the Andrée narrative, stretched to the limit but essential to the totality.

Summing up, the Andrée Museum has gradually changed from a memorial site into a theme museum, fitted into a diverse cultural centre, in an attempt to remain relevant both locally and nationally. Along the way, the early efforts to fit the town of Gränna into the Andrée narrative have been replaced by efforts to justify Andrée's position in the local context. In contrast, the Fram Museum is still a memorial museum, disengaged from local ties and presenting narratives that are largely unaltered but nevertheless nationally relevant.

\section{Museum, Narrative and Nation}

With all the public support and attention attached to their expeditions, explorers like Andrée and Nansen, balancing on the thin line between science and spectacle, became trapped in the stories they had constructed around their own persons. There was no turning back, no alternatives but to succeed or die while trying. Similarly, the museums erected around their performances and persons have become entrapped by the strong narratives that they relate. These captives of narrative are dealing in different ways with their situation.

What has been uncovered by this comparison is not mainly a case of institutions that are either modern or outdated. Instead it could be argued that both museums quite clearly express what it means to be a modern polar nation, but they do it in different ways. Sweden and Norway both claim active roles in present polar science and especially Norway retains commercial, industrial and geo-political 
interests in the regions. In the Norwegian case, however, there has been a remarkable continuity in these ambitions, from the times of the Fram expeditions to the present. While Norway's polar efforts have developed and its scientific ventures have unfolded, the link to the Nansen tradition has been kept intact. This is not least a question of rhetoric and framing - recent exploits and the actors behind them refer explicitly to the distant past. For Sweden's part, a more distinctive breach can be discerned, essentially taking place during the decades of the Andrée expedition's absence. From necessity rather than out of free will, Sweden's strategic claims were revised on several points during these important years. The industrial and geo-political claims of the $19^{\text {th }}$ century were abandoned, and a new scientific ideal, distanced from the individual explorer-hero, was introduced (Sörlin 1994). With the unexpected reappearance of the White Island Findings, these changes became apparent, and they have made the museum display problematic ever since.

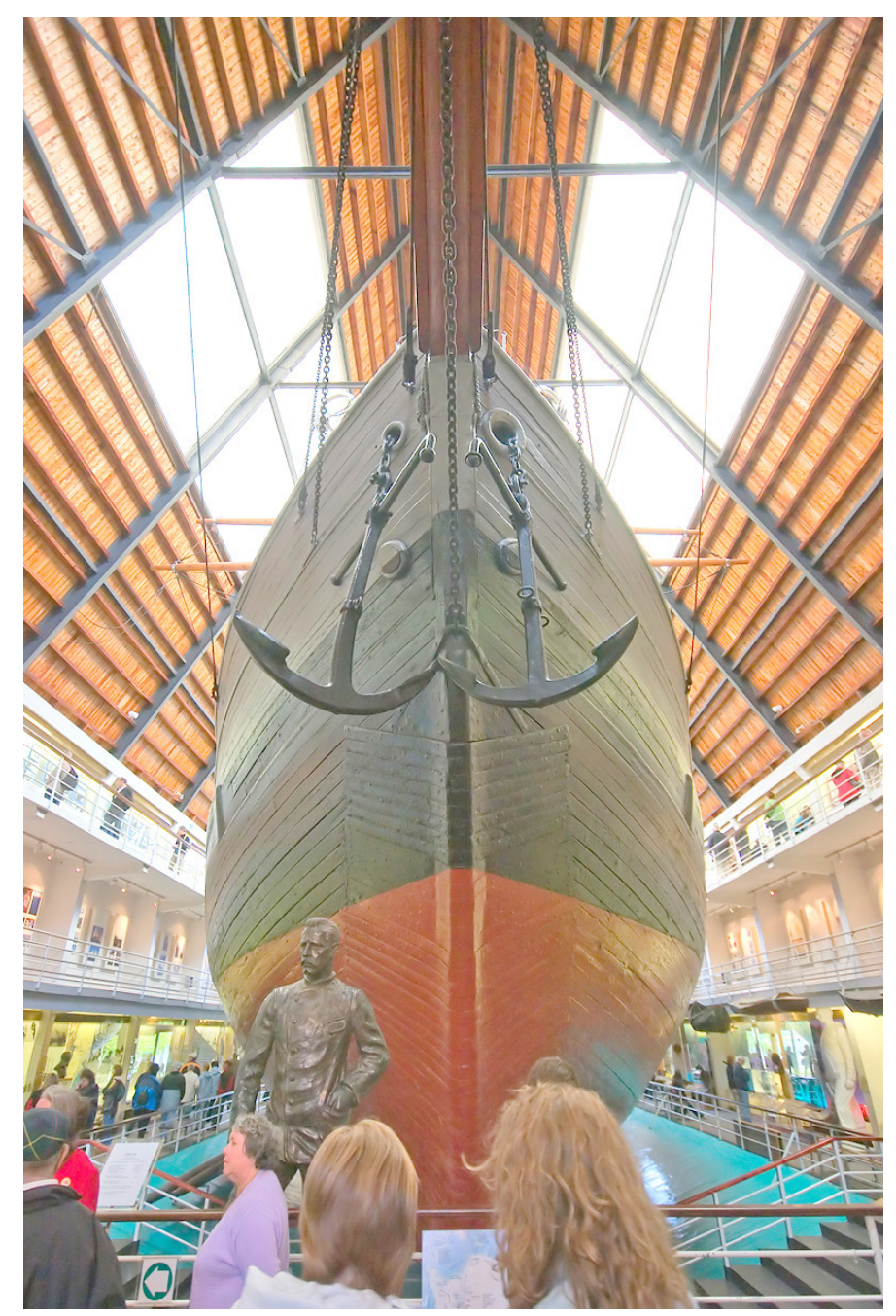

Since 1993, Fridtjof Nansen welcomes visitors to the Fram Museum in the shape of a statue by Per Ung (photo: Anders Houltz). 
The breach has further implications than that. During the inter-war years, the foundation for a revised national identity was laid both politically and culturally; the development of a modern Sweden of large-scale solutions in society as in industry, of rationality and progress rather than history. In this revised grand narrative, to which S A Andrée most likely would have had few personal objections, the symbolic figure which he had become ironically enough fitted badly. In Norway it can be argued that the significant breach with history came earlier and was due to quite different factors. The crucial point seems to be connected to the nationalist awakening of the late $19^{\text {th }}$ century and the subsequent creation of a common national identity, culminating with the dissolved union with Sweden and independence in 1905. The Fram and all it represents was a part of this grand narrative right from the start, and still is.

With the intention to contribute to the largely uncovered research field of polar museums and their narratives, I have here focused on two institutions and two nations. A further analysis would certainly gain from a widened scope, including other nations and other museums, both in the Nordic countries and, for instance Russia, USA and Great Britain. Already the present comparison is, however, sufficient to point out the relation between museum and narrative, as well as the relation between individual museums and the grand narratives of nations. Indeed museums, and polar museums not least, offer efficient arenas for conveying national self-images. Giving prominence to historical individuals and their narratives as either metaphors or examples has proved a useful method for museums as nation building institutions, and in this sense polar explorers with their heroic aura appear well-suited, at least historically. The museums provided the distant events of polar explorers with a home-setting, more or less firmly tied to, and gradually revised in relation to, contemporary issues. This ability to contextualize and recontextualize essential narratives without loss of credibility and with unchallenged truth claims is one of the distinctive features of the museum as a medium, compared to for instance newspapers. This asset can, however, turn into a hazard when museums become entrapped by the narratives they depend upon

The two museums compared in this article are both in different ways captives of their own narratives. In the Norwegian case the museum is permeated by a story that seems nearly impossible to revise. What makes revision so difficult (and even perhaps appear unnecessary) is the fact that the narrative is tightly interlaced with the grand narrative of modern Norway. In the Swedish case, the entrapment works the other way. The narrative is a foundation, but its national and local relevance is no longer evident. The ambivalence is apparent in the exhibitions, and in the continuous efforts to revise them. In relation to the grand narrative of modern Sweden, the story of S A Andrée and his expedition is, at most, a counternarrative. 
Anders Houltz, Ph D, is a researcher at the Division for the History of Science and Technology, KTH, Stockholm. Research interests: The cultural history of technology and industry, museums, exhibitions and medialization, material and visual culture. E-mail: houltz@kth.se.

\section{Notes}

1 Nansen's later engagements, both as a leading force in the abolishment of the SwedishNorwegian union and as a humanitarian activist and diplomat (earning him the Nobel Peace Prize in 1922), are most likely important additional reasons for his long-lived national popularity. It is worth noticing that no less than three out of top 10 on the list were explorers (Nansen, Roald Amundsen and Thor Heyerdahl). In a comparable Swedish vote for the "Swede of the century", the writer Astrid Lindgren ended up in first place and no explorers were among the top 20 (Aftonbladet, 1999-12-31).

2 In for instance "På ski over fjellet" from 1884, Nansen expounds on the nature-given relationship between Norwegians and skiing. In: Eventyrlyst Oslo 1995.

3 Correspondence between A E Bolling and Prof. Hans W:son Ahlmann, SSAG, 1932-11-10; Correspondence between A E Bolling and Birger Barre Advokatkontor, Stockholm 1933-0209. Gränna museers arkiv.

4 Letter from Per Geijer, chairman of SSAG, to the board of Stockholm University, 1945-0212. Royal Academy of Sciences Archive.

5 On the other hand, scholars of other disciplines than the anticipated natural scientists have showed considerable interest - historians of photography and literature as well as conservation scientists etc have all from their different perspectives extracted new knowledge from the White Island Findings (Martinsson 2003).

6 Guide to the Gränna Museums, 1947 (Gränna museers arkiv).

\section{References}

Andrée, Salomon August (1896): Rapport angående 1896 års svenska polarexpedition, Göteborg.

Andrée, Salomon August, Knut Frænkel, et al. (1930): Med Örnen mot polen: Andrées polarexpedition år 1897, Stockholm: Bonniers förlag.

"Andréefynden från Vitön i Stockholms vita konsthall" (1931): Svenska Dagbladet, 5 January 1931.

"Andréeminnet i centrum vid museiinvigningen" (1946): Gränna Tidning, 23 May 1946.

"Andréerum i Hembygdsgården" (1930): Grenna Nya Tidning, 24 October 1930.

"Andréerum i Tekniska museet" (1939): Svenska Dagbladet, 25 August 1930.

"Andrées vilja bör beaktas" (1930): Grenna Nya Tidning, 16 September 1930.

"Andréeutställningen slår rekord" (1931): Svenska Dagbladet, 11 January 1931.

Arctander, August(1934): "Skal Sjöfartsmuseet ofres på Frams alter?”, Dagbladet, 24 May 1934.

Arnesen, Odd (1942): "Fram”: Hele Norges skute, Oslo: Jacob Dybwads Forlag.

Aronsson, Peter (2005): "1905 - unionsupplösning att glömma eller att stoltsera med?", Torbjörn Nilsson \& Øystein Sørensen (eds), Goda grannar eller morska motståndare?: Sverige och Norge från 1814 till idag, Stockholm: Carlssons förlag, 216-248.

(2008): "Comparing National Museums: Methodological Reflections", Peter Aronsson \& Andreas Nyblom (eds): Comparing: National Museums, Territories, Nation-building and Change: NaMu IV, Linköping: Linköping University Press, 5-20. 
(2010): "Explaining National Museums", Simon Knell, Peter Aronsson \& Arne Amundsen (eds): National Museum Studies from around the World, London: Routledge, 29-54.

Avango, Dag (2005): Sveagruvan: Svensk gruvhantering mellan industri, diplomati och geovetenskap 1910-1934, Stockholm: Jernkontoret.

Bal, Mieke (1994): "Telling Objects: A Narrative Perspective on Collecting”, John Elsner \& Roger Cardinal (eds) The Cultures of Collecting, Cambridge, Mass.: Harvard University Press, 97115.

(1996): Double Exposures: The Subject of Cultural Analysis, New York: Routledge.

Borgen, Johan (1934): "Döde minner - eller levende forskning?", Dagbladet, 11 August 1934.

Bravo, Michael \& Sverker Sörlin (eds) (2002): Narrating the Arctic: A Cultural History of Nordic Scientific Practices, Canton, Mass.: Science History Publications.

Christensen, Olav \& Audhild Skoglund (eds) (1996): Nansen ved to århundreskifter, Oslo: Norsk folkemuseum, Aschehoug.

Dahle, Sissel (1999): "Århundrets nordmann", Aftenposten, 13 September 1999.

Drivenes, Einar-Arne \& Harald Dag Jølle (eds) (2005): Norsk polarhistorie I-III, Oslo: Gyldendal. Elvestad, Sven (1934): "Skal Fram bli et monstrum?", Tidens Tegen, 3 October 1934.

Eriksen, Anne (2005): Norsk polarhistorie II. Einar-Arne \& Harald Dag Jølle (eds), Oslo: Gyldendal, 345-390.

(2009): Museum: En kulturhistorie, Oslo: Pax Forlag.

Fram-Avisen (1935): Oslo: Fram kommittén (Norsk Sjøfartsmuseums arkiv).

"Fram-huset ferdig i november" (1934): Dagbladet, 12 August 1934.

Friedman, Robert Marc (2010): "Making the Aurora Norwegian: Science and Image in the Making of a Tradition", Interdisciplinary Science Reviews, 35:1, 51-68.

"Från vaggan i Gränna till graven i polarisen" (1930): Grenna Nya Tidning, 19 September 1930.

"Grännasonen - nationalhjälten" (1930): Grenna Nya Tidning, 26 August 1930.

Huntford, Roland (1997): Nansen: The Explorer as Hero, London: Duckworth.

Huntford, Roland \& Jan Christensen (1996): Fridtjof Nansen: Mennesket bak myten, Oslo: Aschehoug.

”Idag kommer Fram til Oslo for å trekkes på land" (1935): Aftenposten, 6 May 1935.

Joriksson, Håkan (2002): "Andréemuseet 70 år", Ett solvarv $i$ Gränna, 10-15.

Joriksson, Håkan, Inger Ekengard \& Ulla Rosengren (2000): "Dårar och grevar på Grännamuseerna”, Jönköpings-Posten, 3 August 2000.

"Kan Gränna mottaga ett Andréemuseum? - Hembygdsföreningen villig bygga stenhus för ändamålet" (1993): Grenna Nya Tidning, 2 September 1930.

Langset, Mona (1993): "I polaromgivelser", Aftenposten, 21 June 1993.

Larsson Haglund, Ingrid \& Lennart Haglund (2000): "Vi vill ha ett levande, spännande Grännamuseum - inte ett dödens hus präglat av en oansvarig persons dåraktiga handling”, JönköpingsPosten, 25 July 2000.

Lidén, Svante (1999): "Århundradets svensk", Aftonbladet, 31 December 1999.

Lundström, Sven (ed) (1991): Andréemuseet 1997: Framtiden för det förgångna, Gränna: Grännamuseerna.

Lundström, Sven (1991): "En ny bild av Andrée - eller håller den gamla även i framtiden?", Sven Lundström (ed): Andréemuseet 1997: Framtiden för det förgångna, Gränna: Grännamuseerna, 77-88.

Martinsson, Tyrone (2006): Nils Strindberg: En biografi om fotografen på Andrées polarexpedition, Lund: Historiska Media.

Martinsson, Tyrone (2003): Photographic Archaeology and Nils Strindberg's Photographs from the Andrée Polar Expedition 1896-1897, London: Univ. of Westminster.

Moland, Tallak (1999): "Konstruksjon av mandighet i det nordlige landskapet: Om Fridtjof Nansens polarferder ved århundreskiftet”, Anne Marie Berggren (ed): Manligt och omanligt i ett historiskt perspektiv, Stockholm: Forskningsrådsnämnden, 213-221.

Nansen, Fridtjof (1897): Farthest North: Being the Record of a Voyage of Exploration of the Ship Fram 1893-96, London: Westminster.

Nansen, Fridtjof (1962): Eventyrlyst: Artikler og taler, Oslo: Aschehoug.

Nansen, Fridtjof (1905): Norway and the Union With Sweden, London. 
Nilsson, Torbjörn \& Øystein Sørensen (eds): Goda grannar eller morska motståndare?: Sverige och Norge från 1814 till idag, Stockholm: Carlssons förlag.

Pedersen, Ragnar (2003): "Noen trekk av museenes historie i Norge frem til tidlig 1900-tall", Arne Amundsen, Bjarne Rogan \& Margarethe C. Stang (eds): Museer i fortid og nåtid: Essays $i$ museumskunnskap, Oslo: Novus forlag.

Pettersson Kymmer, Peter (1993): "Andréemuseet blir nytt polarcentrum", Göteborgs-Posten, 28 March 1993.

Rasle (sign.) (1934): "Det hellige skib", Morgonbladet, 20 October 1934.

"Tillfällig utställning av fynden - Nordiska museets hall får disponeras - Andrée bör få museum" (1930): Svenska Dagbladet, 24 August 1930.

Robinson, Michael F. (2006): The Coldest Crucible: Arctic Exploration and American Culture, Chicago: University of Chicago Press.

Rydén, Per (2003): Den svenske Ikaros: Berättelserna om Andrée, Stockholm: Carlssons förlag.

Sejersted, Francis (2005): "1905 i norsk historie: Minner og myter" Historisk tidsskrift (Oslo) $84: 2,229-238$.

Sörlin, Sverker (1994): "Svensk polarforskning före Polarforskningssekretariatet", Susanne Eriksson (ed): Polarforskning och expeditioner: Polarforskningssekretariatet 1984-1994, Stockholm: Polarforskningssekretariatet, 7-17.

(1999): "The Burial of an Era: The Home-coming of Andrée as a National Event", Urban Wråkberg (ed): The Centennial of S A Andrée's North Pole Expedition: Proceedings of a Conference on S A Andrée and the Agenda for Social Science Research of the Polar Regions, Stockholm: Royal Swedish Academy of Science, 100-111.

Trondsen, Flemming (2009): "Nasjonalskatt naer svidd av", Aftenposten, 11 March 2009.

Törnvall, Gunilla (2002): Dokumenten från Vitön: En undersökning kring ett materials historia och framtid, Göteborg: Göteborgs univertsitet.

"Vitömuseet i Gränna" (1946): Svenska Dagbladet, 18 July 1946.

"Värdefulla bidrag till Andréerummet" (1930): Grenna Nya Tidning, 7 November 1930.

Wheeler, Barbara \& Linda Young (2000) "Antarctica in Museums: The Mawson Collections in Australia”, Polar Record, 36: 198, 193-202.

Wråkberg, Urban (1998): "Hundra år av historieskrivning kring S.A. Andrée och hans polarexpedition", Ymer, 117, 60-79.

(1999): Vetenskapens vikingatåg: Perspektiv på svensk polarforskning 1860-1930, Stockholm: Kungl. Vetenskapsakademien. 